\title{
The Uniqueness of Mangrove Forests in State of Sabah as a Source of Natural Color on Batik Fabric
}

\author{
Erren Jossie Baeren ${ }^{1, *}$ Humin Jusilin ${ }^{2}$ \\ ${ }^{I}$ (MA) Faculty of Humanities, Arts and Heritage. University of Malaysia Sabah \\ *Email: errenjossie@yahoo.com \\ 2 (Ph.D.)Faculty of Humanities, Arts and Heritage. University Of Malaysia Sabah \\ *Email:zumin198@yahoo..com
}

\begin{abstract}
Mangrove swamp forests in Malaysia can reach maturity up to over 70 years and have 100 mangrove swamps that cannot sin other countries. Mangrove swamps are coastal wetlands that cannot find around the tropics and subtropics. The characterized Mangrove plants as halophyte trees live in high salt content areas and grow in tidal waters. In Sabah, the Kota Kinabalu Wetlands Conservation Society (Sabah Wetlands Conservation Society) preserved the unique mangrove swamp with 24 hectares hidden behind the rapid development of the State of Sabah capital. In this research, researchers researched Rhizophora Apiculata Blum. Trees and Rhizophora Mucronata Lam. as one source of coloring on batik cotton fabric. Mangrove tree structures have the potential to produce color pigments. Techniques used in color production on batik cotton fabric include mordanting technique, batik canting technique, material extraction technique, fixation technique, wax removal, and experimental colorfastness on batik fabric sampling. Throughout this research, mangrove trees are still well preserved-besides, Rhizophora apiculata Blum. Rhizophora mucronata Lam. trees can produce various colors that can guide the textile industry and batik industry in Sabah and worldwide.
\end{abstract}

Keywords: Natural Color, Rhizophora apiculata Blum, Rhizophora mucronata Lam., Batik Industry, Textile Industry

\section{INTRODUCTION}

Batik is a painting produced through dots that form a line on the fabric (Soekamto, 1984: 9). Didik Riyanto (1993: 5) states that batik comes from the Javanese language called "mbatik," or means dots. Batik is a painting activity on the surface of a fabric. Batik paintings or motifs usually produced using batik tools such as canting and wax (Anne Richter, 1994: 90).

During the German and Dutch rule, they strictly prohibited textile products using chemicals such as diazonium salts. Because it identifies the effect of using color synthesized with diazonium, salt causes cancer and is a silent killer. Nowadays, awareness of natural color (back to nature) in the world of baptism shows awareness to society to diversify natural color sources at once led to the batik industry's development (Sambas in Tity Soegiarti: 2002).

Natural colors produced through the content of natural materials available on this earth can use a source of coloring. In ancient times, natural colors have long had used to color fabrics and threads derived from natural fibers. Natural colors have their uniqueness and get public attention because of their exquisite color results. Most of the works or fabrics produced from natural colors have a very high value than the existing colors.

People nowadays are increasingly aware of the importance of preserving and conserving forests in providing comfort or well-being. Green plants provide clean and comfortable air that can calm the mind through beautiful scenery, supply clean water sources, and be home to various flora and fauna species. Among the species that grow in marshy forest areas are Mango Oil (Rhizophora apiculata) and Mangrove Mange (Rhizophora mucronata).

Mangrove forests in Malaysia can reach maturity up to more than 70 years and have 100 mangrove plants not found in other countries. Mangrove swamps are coastal wetlands that cannot find around the tropics and subtropics. The characterized Mangrove plants as halophyte trees live in high salt content areas and grow in tidal waters. In Sabah, the Kota Kinabalu Wetlands 
Conservation Society (Sabah Wetlands Conservation Society) preserved the unique mangrove swamp with 24 hectares hidden behind the Sabah State's rapid development capital.

\section{RESEARCH METHODOLOGY}

These research experiments are doing based on Batik Studio. Mangrove roots obtained from the Sabah Wetlands Conservation Society Ramsar Site. Researchers are exploring natural colors that have the potential to produce natural colors on batik fabrics. InState of Sabah, most natural colors are still on to handicrafts such as weaving. Also, the batik industry in Sabah focuses only on the existing coloring (chemical color). Furthermore, the colors produced have their history that is the mythical story of every ethnic group in the State of Sabah. Low Kok On (2003: 21-22) states that the role of myths in the past related to the origin of man and the existence of the universe.

In the beginning, the researcher collects information from reading, such as books, theses, articles, journals, and related papers. Besides, researchers meet up with informers in institutions and studios that have skilled in natural dye batik. They are from lecturer and student from D3 Batik Technology Study Program, Pekalongan University (UNIKAL), Zahir Wadadi Batik Studio, and the opportunity to visit the Pekalongan Batik Museum, Central Java, Indonesia.

The information got to use as detailed experimental data. The interview procedures in this research are to support accurate data. Researchers interviewed and trained in the Zahir Widadi Batik Studio and at the D3 Study program, Batik Technology (UNIKAL). Besides, the interview also involved several individuals and batik entrepreneurs.

\section{MORDANTING PROCESS}

In this experiment, the mordanting process removes impurities on the fabric to facilitate color pigment to permeate the fabric fibers. After staining on the fabric, the researchers use soda ash and alum color enhancers and increase fire resistance. T.he following are the stepby-step fabric preparation methods used in the experiment (Figure 1: i to v).

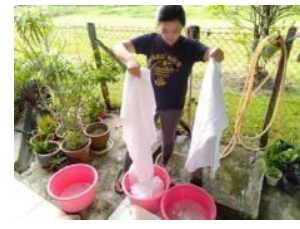

(i)

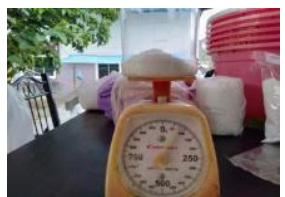

(iii)

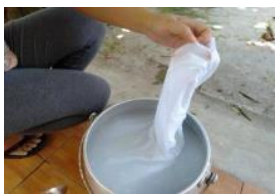

(vi)

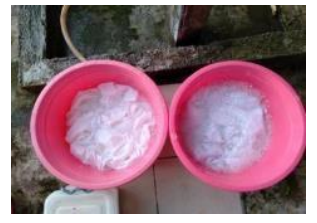

(ii)

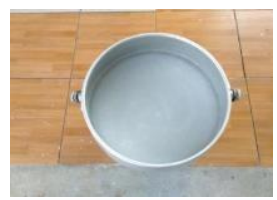

(iv)

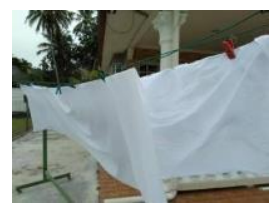

(v)
Figure $1(\mathrm{i}-\mathrm{v})$ : Mordanting Process of Cotton Fabric

After the mordanting process, the experiment begins with natural resource extraction to get a color pigment. The result of pigment needs to wait until cool. Then strain the extracted pigment from the natural ingredients. The coloring process begins by inserting the fabric into the dye pigment. Dyeing batik fabric involves several times until it gets the desired color. The more dips, the brighter the color obtained.

\section{BATIK STAMP}

Batik in Malaysia produce through several techniques, processes, and styles; one technique is the batik stamp. To make many designs with a variety of designs on the block and stamping into the fabric. On the East Coast, it is better known as Batik Cap or Batik terap. The initial process in making batik stamps is to use woodblock nest carving to taste a natural black dye. They call this ancient technique called 'Black-based.' In the 1920s, wax in the application process was first introduced by batik makers on the East Coast until the blocks made of Juda steel sheets introduce. These steel block patterns are neater and finely crafted. A long time ago, batik makers provided special blocks to apply wax on the Fabric Head, Cloth Fabric, and Cloth Body. 


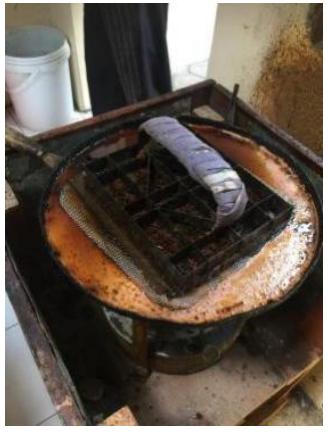

(i)

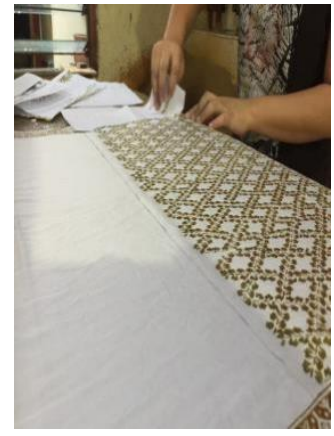

(ii)
Figure 2 (i-ii): Process Of Batik Stamping Using Block

Batik stamp is one favorite of residents. They were usually often using batik sarong and batik ela. Besides using a cloth in daily life, they used their creativity to produce sheets, curtains, mattresses, cushion covers, pillowcases, handbags, and various beauties they have produced every day.

\section{FIXER NATURAL COLOR MATERIAL}

The color fixation on batik fabric is for binding and evoking natural colors after the dyeing process. Among the color fixation used are as follows (Figure 3 : i to iv).

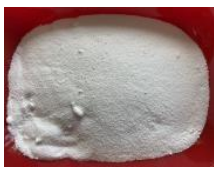

(i) Kapur

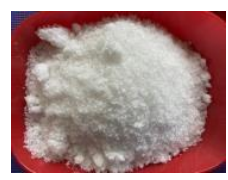

(ii) Tawas

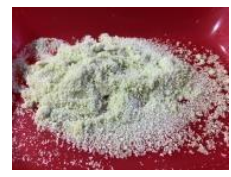

(iii) Tunjung

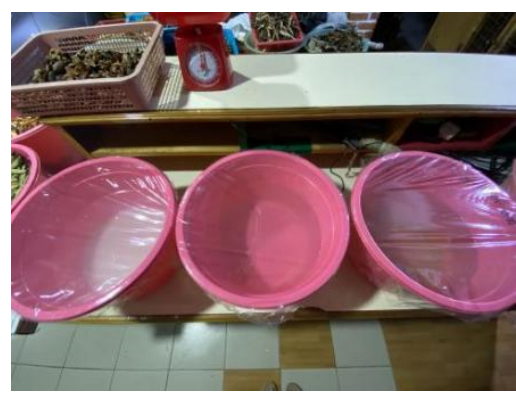

(iv)

Before starting producing dyes, the thing that should prepare first is the color fixation because it has to go through a sedimentation process for a day (Figure 1).

\section{EXPERIMENT ROOTS OF OIL MANGROVE TREE (RHIZOPHORA APICULATA BLUM.)}

Mangrove Oil grows in tidal areas where these areas comprise soft, muddy soil. This tree has long roots that function to adapt to the conditions of the muddy area.

Besides having an extensive root system, most mature trees have supportive roots that grow downwards. These roots come out of the large branches below, and they function naturally to keep the tree from falling by the waves and strong winds.

This species has yellow flowers. Oil mangrove flowers have propagules that have a size of about 35 centimeters long in dark green. Leaves are thick and pointed at the ends. We can distinguish oil mangrove in morphological properties with mangrove ringworm that do not have spots on the leaves' back surface and the spine and stems of reddish leaves. The experiment color of oil mangrove roots as follows (Figure 4: i to xii).

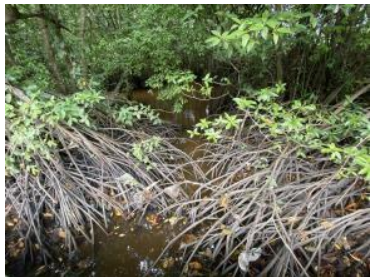

i.

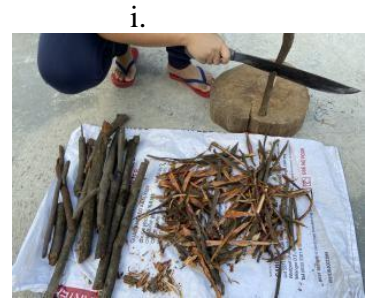

iii.
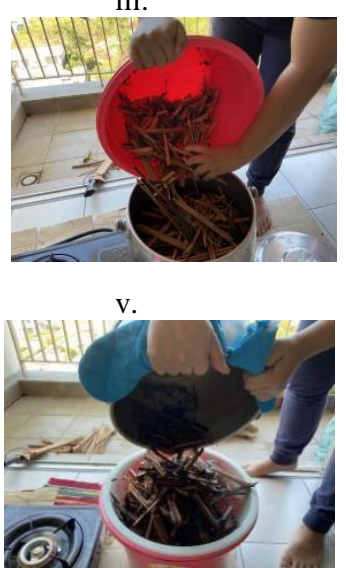

vii.

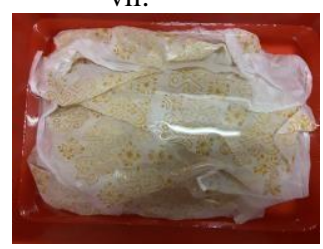

ix.

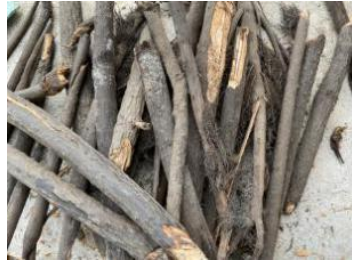

ii.

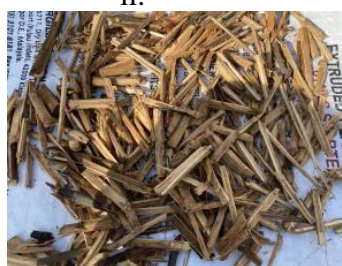

iv.

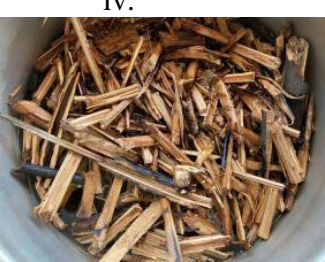

vi.

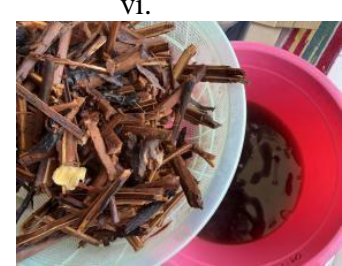

viii.

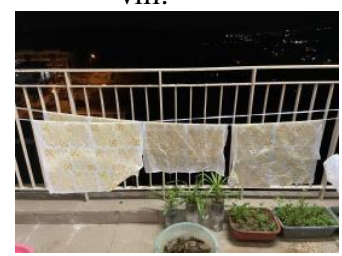

$\mathrm{x}$. 


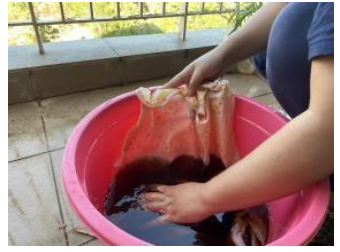

$\mathrm{xi}$.

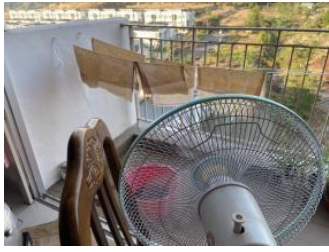

xii.

Figure 4 (i- xii) : Experimental Roots of Oil Mangrove Tree (Rhizophora Apiculata Blum.)

\section{EXPERIMENT COLOR OF LOOP-ROOT MANGROVE TREE (RHIZOPHORA MUCRONATA LAM.)}

Rhizophora Mucronata was found in Malaysia and extended to northeastern Australia, Melanesia, and Micronesia. Mangrove mange is a tree that has a height of $27 \mathrm{~mm}$ and almost reaches $30 \mathrm{~mm}$, and the stem diameter up to $70 \mathrm{~cm}$. This plant looks like a cliff-like Rhizophora Apiculata. Besides, wood from Rhizophora Mucronata has a benefit that can make fuel and charcoal.

Loop-root mangrove has bark that looked like dark grey and dark brown. We can see prop roots and stilt roots at the lower part of the tree. These roots can help give oxygen to the plant that scarce in the waterlogged soil. These roots can also spread over a wide area to help stabilize the tree on the unstable ground. Experiments color of oil mangrove root mange as (Figure 8.0: i to ix)
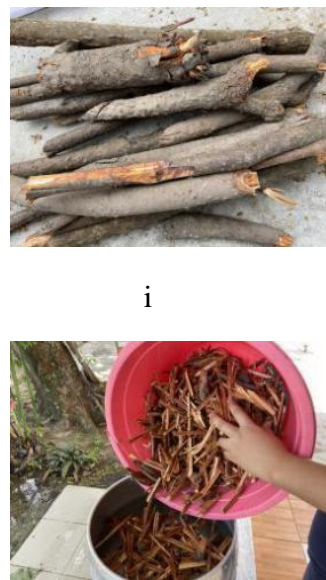

iii

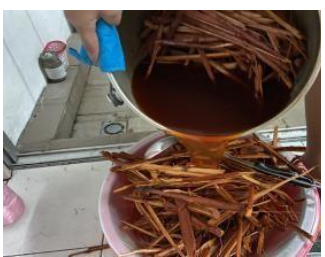

V

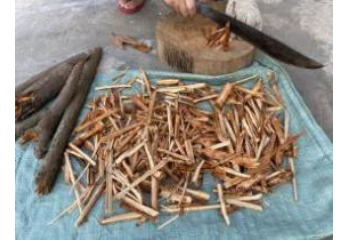

ii.

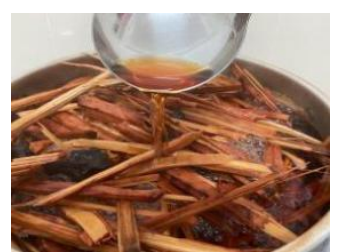

iv

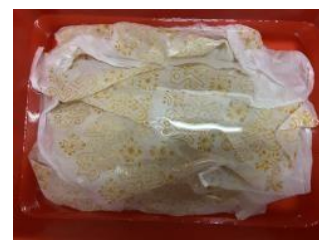

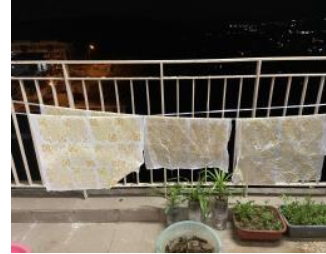

vii

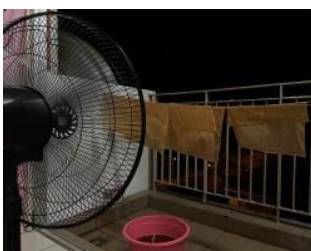

ix

Figure 5 (i - ix): Experiment Color of Loop-Root Mangrove Tree (Rhizophora Mucronata Lam.)

\section{FIXATION COLOR SAMPLING}

Figure 6 is a process of fixation color after the dyeing process on the batik fabric sample. This experiment uses 3 components of copper to help the color, such as lime, alum, and tunjung (Figure 6: $\mathrm{i}$ to ii).

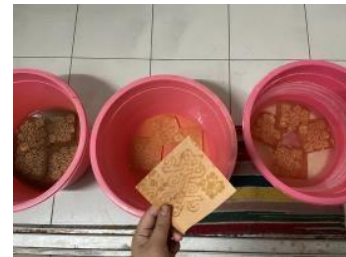

(i)

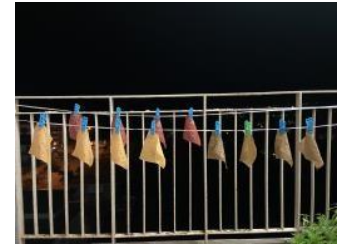

(ii)
Figure 6 (i-ii): Fixation Color Process

\section{COLOR FASTNESS}

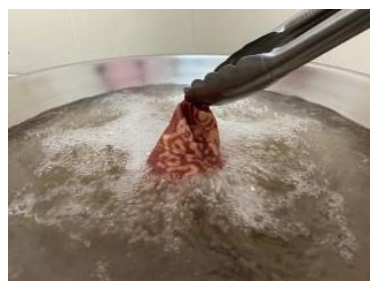

Figure 7: Boiling Process for Experimental Color Fastness

Figure 7 is a boiling process. The process is a physical change, and molecules do not chemically alter during the process. This process aims to test the color fastness on batik fabric while removing batik wax for around 10 minutes in boil water. 


\section{EXPERIMENT RESULT}

\subsection{Sampling of Natural Color Produce On Batik Fabric}

6

$\mathrm{x}$

12
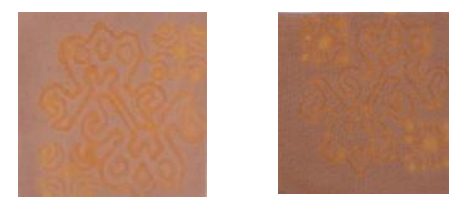

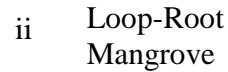
(Root)
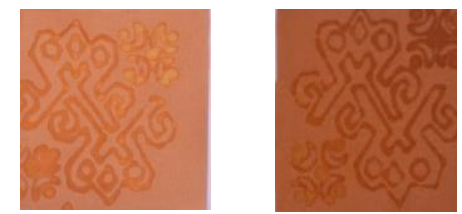

Figure 8 (i-ii): Experimental Result Sampling of Natural Color Dye Batik Fabric

Figure 11.1.1 (i-ii) shown the results of sampling natural dye batik fabric using Oil Mangrove Root and Loop-Root Mangrove. The dip colors on batik fabric were $6 \times 2$, which is 12 times all dip color. The sampling of 12 times produces a darker color, while 6 times colors dip produce a light color. The oil mangrove root produces a brown color, while the loop-root mangrove root produces a reddish-orange color.

\subsection{Experiment Result Color Fastness On Natural Dye Batik Fabric Sampling}

\subsubsection{Color Fastness Natural Color Of Oil} Mangrove Tree Root Before Boiling

\begin{tabular}{|c|c|}
\hline Natural & Oil Mangrove Root (Before) \\
\hline & Fixer \\
\hline
\end{tabular}

$6 x$
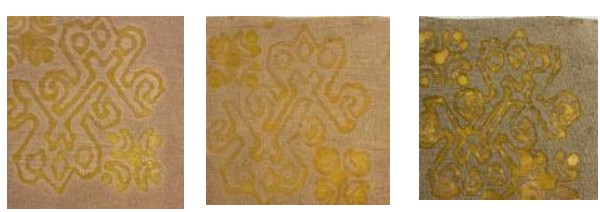

$12 \mathrm{x}$
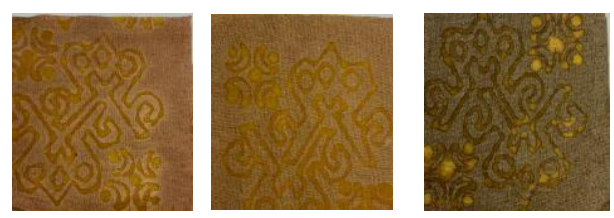

Figure 9: Experimental Result Sampling Oil Mangrove Tree Root After Boiling

Figure 9 is a sampling of experiment batik fabric using natural dye from roots Oil Mangrove. The result obtains before the boiling process. Through the experimental results, batik fabric 12 times of color dip is darker than 6 times color dipping. Besides, alum produces color light brown color, lime produces a little dark brown color, while tunjung produces a darker brown color towards grey.

\subsubsection{Color Fastness Natural Color Root Of Oil Mangrove Tree Root After Boiling}

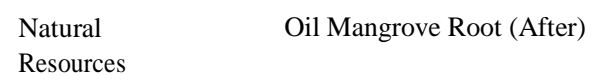

Alum

Tunjung

$6 x$
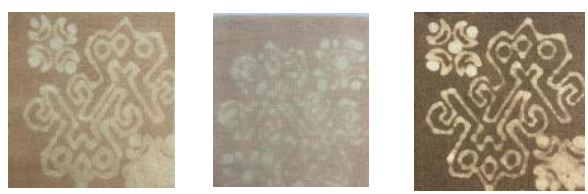

$12 \mathrm{x}$
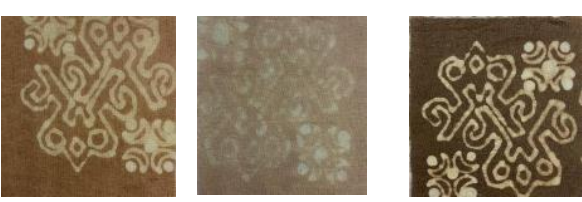

Figure 10 : Experimental Result Sampling Oil Mangrove Tree Root After Boiling

Figure 10 after the batik fabric sampling already boiled for around 10 minutes, the color more faded than before, the experiment results of 12 times dip color produce a darker color rather than the 6 times color dipping. Alum produces a very light color. Lime produces a bit dark and very soft color than before, while tunjung produces a darker brown color. 


\subsubsection{Color Fastness Natural Color Loop-Root Mangrove Tree Root Before Boiling}

Natural $\quad$ Loop-Root Mangrove Tree (Before)
Resource

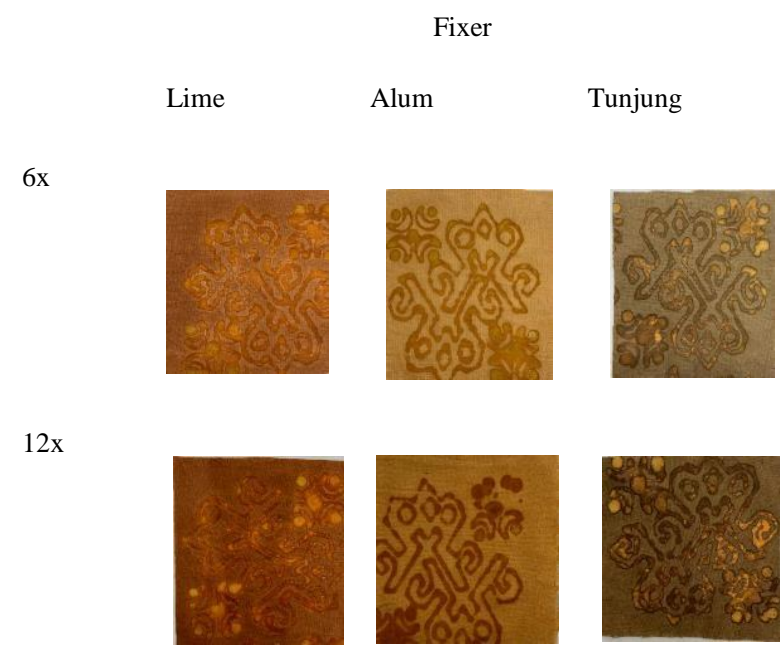

Figure 11 : Experimental Result Sampling loop-root Mangrove Tree Before Boiling

Figure 11 results from natural color batik sampling using loop-root mangrove on batik fabric before the boiling process. Throughout the experimental results, 12 times of color dip look darker than 6 times of color dipping. Alum produces a light brown color. Lime produces a bit of dark reddish-brown color, while tunjung produces a darker brown color like grey.

\section{COLOR FASTNESS NATURAL COLOR LOOP-ROOT MANGROVE TREE ROOT AFTER BOILING}

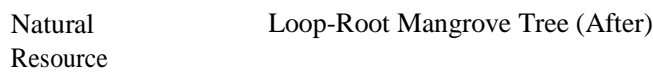

Loop-Root Mangrove Tree (After)

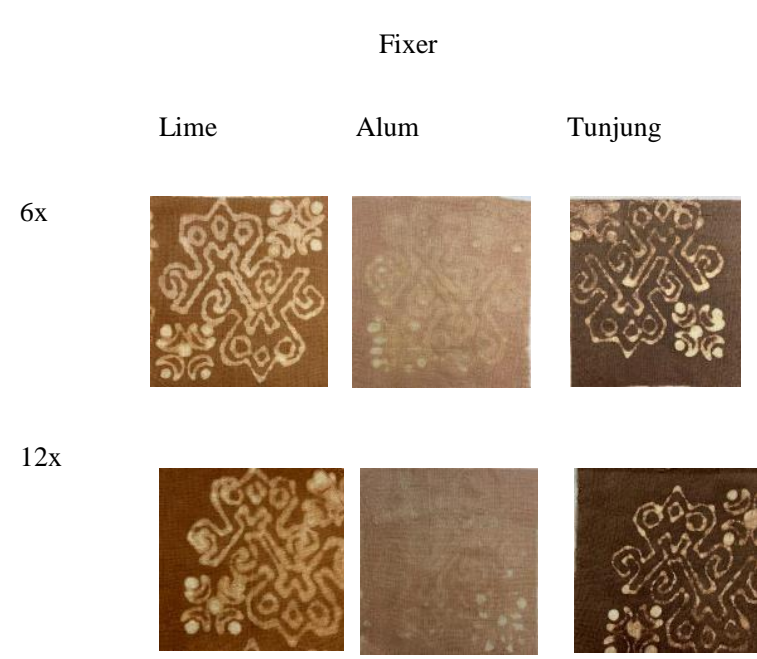

Figure 12: Experimental Result Sampling loop-root Mangrove Tree Root on Batik Fabric After Boiling
After the boiling process, around 10 minutes, the color sampling of batik fabric using loop-root mangrove produces a more faded color rather than before. The 12 times color dip results still look darker rather than the sampling dip around 6 times. Alum produces more color light, and lime produces a dark color, while tunjung produces a darker brown color.

\section{CONCLUSION}

Natural color extraction of oil mangrove root produces a brown color, and the loop-root mangrove produces a reddish-orange color where the dyeing process is done around 2 hours, its total 10 minutes for each color dipping process, 15 minutes color dipping and 5 minutes are dried the batik fabric in the dark places. The fan is an initiative of auxiliary materials that can speed up the drying process.

The dyeing process rates 6 times which researcher produces a batik sampling 6 times of color dip and 12 times color dipping. The color result on batik fabric at 12 times color dip produces a darker color, while 6 times the color dipping produces a light color. The more color dip has done, the darker color produces on batik fabric.

In this experiment, researchers used the composition of natural resources around $1 \mathrm{~kg}$ equivalent with 10 liters of water for the extraction process and will extract in 1 hour. When the process extract has done, the color pigment produces half of the previous water extraction. 10 liters when extraction color started and the pigment produces half of the stainless steel cooking pot, which means 5 liters.

The color fixation used in this experiment is lime, alum, and tunjung. Lime produces a dark color, alum produces light color, and tunjung produces a darker color. Each fixer materials can produce various colors.

Removing wax on batik is a must. After all, the researcher tested the color fastness on batik fabric while removing the batik wax, which the color has tested in the boiled water for around 10 minutes. From this experiment, natural color sampling on batik fabric faded after the boiling process.

Through the experiments conducted, the researcher using the theory color of Albert Munsell M. as an indicator for color study on this experiment, such as the light color and dark color at the first and last color dip, fixation color until the process of colorfastness on batik fabric.

In conclusion, the ideal color applied to the batik fabric results from 12 times of color dip using lime and tunjung, which ideally applied to batik fabric. Alum produces a light color, but the color produces more faded 
than before when boiled around 10 minutes. Natural color extraction of oil mangrove tree root produces a brown color, and the loop-root mangrove produces a reddishorange color, which the coloring process is done around 60 minutes and dried in the dark places. The fan is an initiative of auxiliary materials that can speed up the drying process.

\section{ACKNOWLEDGMENT}

Sabah is rich with natural resources and has the potential to produce various natural colors. In Sabah, produces natural colors are still limited to yarn in the weaving field. Sabah ethnic has a pearl of wisdom and creativity; this research needs continued to produce more colors. Therefore, these experiments need to expand to obtain an outstanding quality of natural colors and methods. Researchers are very grateful to the lecturers and students of Program Studi D3 Batik Technology, Universitas Pekalongan (UNIKAL), who provided guidance and cooperated in obtaining the necessary data sources in this research. Also, appreciation and millions, thanks to the Sabah Wetlands Conservation Society for providing opportunities and cooperation in making this research succeed.

\section{REFERENCES}

[1]. Asti Musman dan Ambar B.Arini. 2011. Batik Warisan Adiluhung Nusantara. Yogyakarta: Andi Offset.

[2]. American Fabric. 1963. Batik: Designs and Colors. New York: Doric Publishing, Conel University.

[3]. Low Kok On. 2003. Membaca Masa Silam Kadazandusun Berasakan Mitos dan Lagenda: Universiti Sains Malaysia, Pulau Pinang.

[4]. Mahirwono, dkk. 1989. Khasiat dan Manfaat Buah Rambutan. Jakarta: Surya Cipta.
[5]. Riyanto, Didik, SE. 1993. Proses Batik (Batik Tulis, Batik Cap, Batik Printing). Solo: CV. Aneka.

[6]. Richter, Anne. 1994. Arts and Crafts of Indonesia. San Francisco: Chronicle Books.

[7]. Soekamto, Chandra Irawan. 1984. Batik dan Membatik. Jakarta: Akadoma.

[8]. Sambas, M. Moch Sabarudin. 1999. Kemungkinan Pembudidayaan Tanaman BahanPewarna dan Pengunaanya. Makalah dalam Seminar Dekranas tanggal 3-4 Maret 1999. Yogayargata: Dekranas.

[9]. Sancaya Rini, dkk. 2011. Pesona warna Alami Indonesia. Jakarta: Kehati.

[10]. Wijayakusuma, H., Dalimartha, S., dan Wirian, A., 1996, Tanaman Berkhasiat Obat di Indonesia. Jilid ke-4. Jakarta: Pustaka Kartini.

[11]. Yates, Barbara A. "The Art of Batik in Indonesia." School Arts. LX, January, 1961. 7-10.

\section{APPENDIX}

Agustina Rosalinda. 20 Tahun. Universitas Pekalongan (UNIKAL), Jawa Tengah, Indonesia.

Karlina Yunita. 21 Tahun. Universitas Pekalongan (UNIKAL), Jawa Tengah, Indonesia.

Tapak Ramsar Tanah Lembap Kota Kinabalu (Sabah Wetlands Conservation Society)

Zahir Widadi. 55 Tahun. . Universitas Pekalongan (UNIKAL), Jawa Tengah, Indonesia.

Sabah Wetland Conservation Society, Kota Kinabalu, Sabah. 